\title{
SOSIALISASI ADAPTASI KEBIASAAN BARU DI RT 5 / RW 11, KELURAHAN KALISARI, KECAMATAN PASAR REBO, JAKARTA TIMUR MENGHADAPI PANDEMI COVID-19
}

\section{COUNSELING ABOUT NEW NORMAL ADAPTATION FACING PANDEMI COVID-19 AT RT 5 / RW 11, KELURAHAN KALISARI, KECAMATAN PASAR REBO, JAKARTA TIMUR}

\author{
Selvia Febriana Astuti ${ }^{1}$, Latifa Nursyabania ${ }^{1}$, Muhammad Jabbar Falih ${ }^{1}$,Samiyya \\ Rosyid Attamini ${ }^{2}$, Mohammad Rafli ${ }^{3}$, Sri Musta'ina ${ }^{4}$ \\ ${ }^{1}$ Pendidikan Apoteker, Fakultas Farmasi, ${ }^{2}$ Departemen Kimia, Fakultas Sains dan \\ Teknologi, ${ }^{3}$ Departemen Antropologi, Fakultas Ilmu Sosial dan Ilmu Politik. ${ }^{4}$ Fakultas \\ Kedokteran Universitas Airlangga \\ email: sri-m-i@fk.unair.ac.id
}

\begin{abstract}
COVID-19 (Corona Virus Disease 2019) currently becoming a pandemic in various countries, including Indonesia. The highly transmission rate of this disease causes changes in almost all living conditions and patterns of social life. Formerly, the community can freely interact and be close together without any worries, free crowds, no need to use masks, now, all turned into nessecity to apply health protocols such as maintaining distance in interactions, always using masks and washing hands diligently, always implementing the movement of the community to live a healthy life (germas). Such behavior is known as a new normal, or new habit. In DKI Jakarta, one of the areas with the highest increment rate of Covid 19 patient, to break the transmission of Covid-19, the local government imposed a large-scale social restriction (PSBB) which was followed by a transition period towards adapting to new habits. However, statistical data shows that in this transitional period, many people have begun to neglect to implement health protocols that are aimed as new habits to stop pandemics. This is evidenced by the increasing number of people who have contracted Covid-19. To help the local government in its efforts to break the transmission of COVID19, group 288 of the 62nd KKN BBM Mandiri Airlangga University held socialization activities aimed at reminding the community to always comply with health protocols and be diligent to perform disinfection. The socialization activities were carried out in the neighborhood of RT 5 / RW 11 Kalisari Village, Pasar Rebo District, East Jakarta., by posting posters at community gathering points such as mosques, security posts, and parks. Socialization was also carried out online and door-to-door by distributing 180 bottles of disinfectant liquid to residents. It is expected this activity can change the mindset and lifestyle of the local community about the importance of continuing to implement health protocols. Local people are also expected to be more alert and concerned about carrying out regular disinfection in their home environment, especially on items that are often touched and items that have just come from outside the home.
\end{abstract}

Keyword: distribution of disinfectant, COVID-19

\section{abstrak}

COVID-19 (Corona Virus Disease 2019) merupakan penyakit yang saat ini menjadi pandemi diberbagai negara, termasuk Indonesia. Kecepatan penularan penyakit ini, menyebabkan perubahan pada hampir semua kondisi kehidupan serta pola kehidupan bermasyarakat. Dari yang semula masyarakat bisa bebas berinteraksi tanpa harus menjaga jarak, bebas berkerumun, tidak perlu menggunakan masker, menjadi harus menerapkan protokol kesehatan seperti menjaga jarak minimal satu meter dalam berinteraksi, senantiasa 
menggunakan masker dan rajin mencuci tangan, senantiasa menerapkan gerakan masyarakat hidup sehat (germas) . Perilaku seperti demikianlah yang disebut sebagai new normal, atau kebiasaan baru. Di DKI Jakarta, salah satu wilayah dengan tigkat pertambahan jumlah penderita Covid-19 tertinggi, untuk memutus rantai penularan Covid-19, pemerintah setempat memberlakukan pembatasan social berskala besar (PSBB) yang dilanjutkan dengan masa transisi menuju adaptasi kebiasaan baru. Akan tetapi, data statistik menunjukkan, bahwa dimasa transisi penerapan adaptasi kehidupan baru ini, banyak masyarakat sudah mulai lalai menerapkan protokol kesehatan yang disusun sebagai kebiasaan baru untuk menghentikan pandemi. Hal ini dibuktikan dengan kembali meningkatnya jumlah masyarakat yang tertular Covid-19. Untuk membantu pemerintah setempat dalam upaya memutus mata rantai penularan COVID-19, kelompok 288 grup 8 KKN BBM Mandiri Universitas Airlangga ke 62 menyelenggarakan kegiatan sosialiasi yang bertujuan untuk mengingatkan masyarakat disekitarnya agar senantiasa tertib mematuhi protokol kesehatan serta rajin melakukan disinfeksi secara berkala. Kegiatan sosialisasi dilakukan dilingkungan RT 5/RW 11 Kelurahan Kalisari, Kecamatan Pasar Rebo, Jakarta Timur. Metode yang digunakan yaitu pembuatan media cetak berupa poster yang ditempelkan di lokasi yang menjadi titik kumpul masyarakat seperti masjid, poskamling, dan lapangan. Sosialisasi juga dilaksanakan secara daring dan dari pintu-ke-pintu dengan membagikan cairan disinfektan sebanyak 180 botol berisi $100 \mathrm{ml}$ cairan disinfektan kepada warga. Diharapkan kegiatan ini dapat membantu merubah pola pikir dan gaya hidup masyarakat setempat tentang pentingnya tetap melaksanakan protokol kesehatan di masa transisi adaptasi kebiasaan baru ini. Masyarakat setempat juga diharapkan menjadi lebih waspada dan peduli untuk melakukan disinfeksi secara berkala di lingkungan rumah masing-masing, terutama pada barang-barang yang sering disentuh dan barang-barang yang baru datang dari luar rumah.

Kata Kunci: pembagian disinfektan, COVID-19

\section{PENDAHULUAN}

COVID-19 (Corona Virus Disease 2019) adalah penyakit yang disebabkan oleh virus severe acute respiratory syndrome coronavirus 2 (SARS-CoV-2). Penyakit ini pertama kali menjadi wabah dikota Wuhan, Cina dan selanjutnya menyebar ke seluruh dunia. Para pakar melakukan analisis genom, dan menyimpulkan bahwa virus SARS-CoV-2 memiliki filogenetik yang mirip dengan kelelawar, seperti halnya dengan virus SARS$\mathrm{CoV}$ yang menyebabkan penyakit severe acute respiratory syndrome (SARS), pada tahun 2003 (Shereen et al, 2020). Pada tanggal 23 Juni 2020, Data dari situs worldometers.info mencatat jumlah kasus penderita Covid-19 didunia telah mencapai 15.856.353 orang, dengan jumlah kematian sebanyak 602.845 orang dan total pasien yang sembuh sebanyak 8.917.162 orang. Di waktu yang sama, kasus konfirmasi positif COVID-19 Indonesia telah mencapai angka 76.712 orang dengan jumlah kematian sebanyak 3.520 orang dan total pasien yang sembuh sebanyak 47.509 orang, dan di wilayah DKI Jakarta telah terkonfirmasi positif sebanyak 14.496 kasus dengan angka kematian sebesar 698 orang dan total pasien yang sembuh 9.642 orang (Kementerian Kesehatan, 2020).

Dampak yang ditimbulkan pandemi ini sangat dirasakan oleh masyarakat dari berbagai tingkat perekonomian di Indonesia. Pemerintah DKI Jakarta menetapkan berlakunya Pembatasan Berskala Besar (PSBB) untuk memutus mata rantai penyebaran virus. 
PSBB adalah istilah kekarantinaan kesehatan di Indonesia yang didefinisikan sebagai "Pembatasan kegiatan tertentu penduduk dalam suatu wilayah yang diduga terinfeksi penyakit dan/atau terkontaminasi sedemikian rupa untuk mencegah kemungkinan penyebaran penyakit atau kontaminasi" mengharuskan masyarakat untuk tidak keluar dari rumah masing masing. Penerapan ini menyebabkan terhentinya seluruh kegiatan sosial masyarakat. Perekonomian, khususnya tingkat mikro dan kecil, banyak yang harus menutup usaha mereka. Jutaan karyawan dan buruh perusahaan di PHK, menyusul terhentinya operasional perusahaan dan pabrik. Peraturan ini telah dibelakukan sejak pertengahan Maret 2020 yang terus diperpanjang hingga Mei 2020.

Akhirnya pada akhir Mei, Presiden RI Joko Widodo menyatakan akan melaksanakan protokol kesehatan dengan dilaksanakannya 'Adaptasi Kebiasaan Baru' guna untuk memulihkan kembali sektor perekonomian. Kegiatan tersebut resmi berlaku pada 1 Juni 2020 sehingga menghapuskan sistem lockdown daerah. Perlahan sektor perekonomian Indonesia membaik dan dengan diterapkannya kegiatan Adaptasi Kebiasaan Baru dimaksud agar masyarakat dapat bekerja, belajar dan beraktivitas dengan produktif di era Pandemi COVID-19.

Setelah dilaksanakannya Adaptasi Kebiasaan Baru, tidak sedikit masyarakat yang masih ragu untuk keluar rumah dengan alasan takut tertular atau beresiko tertular karena merupakan golongan lansia, ibu dengan anak balita atau bayi, maupun individu dengan penyakit bawaan seperti diabetes dan hipertensi. Sehingga banyak orang menghabiskan waktu dan uang untuk belanja e-commerce. Banyak orang yang memesan barang lewat online lalu saat paket datang, tidak menyemprotkan disinfektan dan langsung menyentuhnya. Seharusnya, penyemprotkan disinfektan pada barang-barang yang berasal dari luar sangat diperlukan karena kita tidak tahu apakah ada virus yang menempel. Dilansir dari situs farmasi.ugm.ac.id disinfektan adalah bahan kimia yang digunakan untuk menghambat atau membunuh mikroorganisme (misalnya pada bakteri, virus dan jamur kecuali spora bakteri) pada permukaan benda mati, seperti furniture, ruangan, lantai, dll oleh karena itu disinfektan tidak digunakan pada kulit maupun selaput lendir, karena berisiko mengiritasi kulit dan berpotensi memicu kanker.

Dalam menghadapi pandemi, banyak hal yang harus dipahami dan dilakukan masyarakat. Perlu dilakukan edukasi kepada masyarakat untuk menjalani adaptasi kebiasaan baru dan penggunaan disinfektan karena minimnya pengetahuan dan kesadaran masyarakat sehingga dapat menekan laju penyebaran COVID-19. Langkah yang dilakukan dalam adaptasi kebiasaan baru ini antara lain yaitu sering mencuci tangan dengan baik dan benar dengan sabun, menghindari menyentuh area wajah (seperti mata, hidung, dan mulut), serta melakukan social distancing yaitu memberikan jarak setidaknya satu meter dengan orang lain. Selain itu, jika batuk dan bersin ditutupi dengan lengan atas atau sapu tangan, menghindari kerumunan dan menerapkan pola hidup bersih dan sehat (PHBS)/gerakan masyarakat hidup sehat (GERMAS) lainnya 
yaitu membersihkan dengan disinfektan secara rutin benda-benda yang sering disentuh di rumah (seperti saklar lampu, gagang pintu,dll).

Dilansir dari situs cdc.gov yang merupakan institusi kesehatan masyarakat nasional Amerika Serika, merilis 351 sediaan/disinfektan yang dapat digunakan untuk membunuh virus termasuk human coronavirus yaitu etanol, sodium hipoklorit, hidrogen peroksida, ammonium kuarterner, terpenoid dan lain-lain. Upaya selanjutnya untuk mempertahankan daya tahan tubuh melawan virus yaitu makanan gizi seimbang (empat sehat lima sempurna) dengan porsi sayur dan buah 2-5 porsi dalam sehari.Dapat diiringi dengan mengonsumsi vitamin dan herbal yang telah teruji untuk mempertahankan daya tubuh.

Selanjutnya, saat beraktivitas diluar rumah harus mengenakan masker. Berdasarkan anjuran dari WHO (World Heatlth Organization) dengan menggunakan masker dapat membatasi frekuensi menyentuh wajah, sehingga mengurangi kontak penyebaran virus. Masker medis lebih diprioritaskan untuk orang berusia lebih dari 60 tahun dan untuk orang yang memiliki penyakit kardiovaskular, diabetes, penyakit paru-paru kronis, penyakit serebrovaskular, kanker dan imunosupresi. Dilansir dari (CNBC Indonesia), WHO juga menganjurkan menggunakan masker kain tiga lapis dengan alasan untuk mencegah orang yang memakai masker tidak menyebarkan virus, tetapi bukan terhindar dari virus, karena itu, penting bahwa mengenakan masker harus selalu disertai dengan seringnya mencuci tangan dan menjaga jarak. WHO juga memiliki bukti melalui penelitian bahwa dengan tiga lapisan dan dalam kombinasi itu, masker kain benar-benar dapat memberikan penghalang mekanistik jika seseorang terinfeksi COVID-19 bisa mencegah tetesan itu melewatinya dan menginfeksi orang lain. Tak lupa selalu membawa hand sanitizer, alat sholat dan alat makan sendiri saat keluar rumah untuk menjaga tangan selalu bersih sesuai dengan anjuran WHO.

Universitas Airlangga melaksanakan Kuliah Kerja Nyata Belajar Bersama Masyarakat (KKN BBM) secara rutin sebanyak 2 kali dalam satu tahun. Pada kesempatan kali ini, KKN BBM Mandiri Ke-62 dilaksanakan pada tanggal 29 Juni 2020 hingga 25 Juli 2020. Lembaga Pengabdian kepada masyarakat (LPPM) Universitas Airlangga menjadi penanggung jawab dalam pelaksanaan KKN BBM Mandiri Ke-62. Pada masa pandemi ini, Universitas Airlangga menyelenggarakan KKN BBM Mandiri dengan menyediakan empat pilar yang dapat dipilih yaitu sosial/lingkungan, ekonomi, pendidikan dan kesehatan. Penulis memilih pilar sosial dan kesehatan yang bertempat di Jakarta Timur khususnya pada lingkungan RT 5/RW 11 kelurahan Kalisari, kecamatan Pasar Rebo, Jakarta Timur. Program KKN BBM Mandiri dilakukan untuk mewujudkan pengamalan Tri Dharma Perguruan Tinggi dan mahasiswa yang mengikuti kegiatan dapat ikut berkontribusi dengan menerapkan dan mengaplikasikan ilmu yang telah diperoleh. Program KKN BBM Mandiri juga dilaksanakan untuk melatih mahasiswa agar dapat beradaptasi di masyarakat serta menerapkan keilmuan yang dimiliki secara langsung. 
Mahasiswa diharapkan dapat memberi solusi dalam permasalahan yang dihadapi di wilayah kerja serta menggali potensi yang ada untuk mengembangkan wilayah kerja.

Secara umum, kondisi geografis/fisik di lingkungan RT 5/RW 11, Kelurahan Kalisari, Kecamatan Pasar Rebo, Kota Jakarta Timur adalah perumahan yang terletak di Kelurahan Kalisari, lokasi tersebut dekat dengan pusat ekonomi UMKM masyarakat sekitar, yaitu warung makan/miunum dan toko kelontong, yang biasanya digunakan masyarakat sebagai tempat berinteraksi. Karena kondisi lingkungan masyarakat terdapat warung dan toko kelontong, membuat masyarakat sekitar berinteraksi dan beraktivitas tidak sesuai protokol kesehatan, sebagian masyarakat yang berkumpul membawa masker tapi tidak menutup wajah mereka dan sebagian lagi tidak menggunakan masker. Selain itu masih terlihat minimnya penyemprotan disinfektan terhadap barangbarang/paket dari luar.

\section{METODE PENGABDIAN MASYARAKAT}

Metode yang digunakan dalam program kerja KKN BBM ke-62 kelompok 288 ini adalah metode penyuluhan dengan pemberian penjelasan pintu-ke-pintu. Penjelasan yang dimaksud mengenai 2 program kerja kami yaitu pembuatan dan pembagian disinfektan, serta program gaya hidup di era Adaptasi Kebiasaan Baru. Penjelasan singkat diberikan kepada warga mengenai pembuatan disinfektan yang benar dan efektif disertai dengan brosur yang juga memuat penjelasan serta botol $100 \mathrm{ml}$ berisi disinfektan hasil dari pembuatan kelompok. Sistem pembagian disinfektan melalui koordinasi dengan ketua RT 5/RW 11 kelurahan Kalisari, dengan membagi kelompok menjadi 2 agar dapat dijangkau 180 rumah dan tidak berkumpul banyak orang.

Program kerja kedua yaitu penjelasan tentang protokol kesehatan yang masih harus dilaksanakan di era Adaptasi Kebiasaan Baru ini. Penjelasan tertuang dalam poster dan spanduk yang dipasang dibeberapa tempat di lingkungan RT 5/RW 11 kelurahan Kalisari agar masyarakat mudah mendapatkan informasi. Poster dan spanduk dibuat semenarik mungkin dan komunikatif sehingga masyarakat awam dapat mengerti.

\section{HASIL DAN PEMBAHASAN}

Menurut KBBI disinfektan merupakan bahan kimia yang digunakan untuk mencegah terjadinya infeksi atau pencemaran oleh jasad renik; obat untuk membasmi kuman penyakit. Sedangkan disinfeksi adalah proses menghilangkan sebagian besar atau semua mikroorganisme patogen kecuali spora bakteri yang terdapat di permukaan benda mati (non-biologis, seperti pakaian, lantai, dinding) (Centers for Disease Control and Prevention, CDC). Disinfeksi dilakukan terhadap permukaan (lantai, dinding, peralatan, dan lain-lain), ruangan, pakaian, dan Alat Pelindung Diri (APD). Benda biasanya didisinfeksi dengan bahan kimia cair atau pasteurisasi basah. Menurut WHO, menyemprotkan disinfektan ke tubuh dapat berbahaya untuk membran mukosa (misal: mata, mulut) sehingga berpotensi menimbulkan risiko terhadap kesehatan dan merusaknya. Penggunaan disinfektan langsung ke tubuh secara terus-menerus dapat 
menyebabkan iritasi kulit dan iritasi pada saluran pernafasan. Selain itu, penggunaan disinfektan jenis larutan hipoklorit pada konsentrasi tinggi dapat mengakibatkan kulit terbakar parah.

Pembagian dan sosialisasi disinfektan dilakukan pada hari Sabtu tanggal 11 Juli 2020 pukul 09.00 - 11.30 WIB di RT 5/RW 11 Kelurahan Kalisari, Kecamatan Pasar Rebo, Jakarta Timur. Kegiatan dimulai dengan membeli dan mempersiapkan barang untuk keperluan pembuatan disinfektan. Pembuatan disinfektan dilakukan sesuai dengan ketentuan Dinas Kesehatan Republik Indonesia yang mengadopsi dari ketentuan WHO (World Health Organization). Pembagian disinfektan dilaksanakan dengan bantuan kader kesehatan dan Ketua RT yang diawali dengan pembagian wilayah tugas oleh Ketua RT, tiga anggota kelompok dan seorang kader kesehatan membagikan di wilayah utara lingkungan RT dan tiga orang lainnya yaitu dua anggota kelompok dan seorang kader kesehatan membagikan di wilayah selatan.

Selanjutnya dilakukan pembagian 180 botol disinfektan yang dibagi dalam dua kelompok, kelompok bagian utara membagikan 90 botol disinfektan dan kelompok bagian selatan membagikan sisanya yaitu 90 botol disinfektan. Disinfektan dibagikan kepada lebih dari 150 warga pada masing-masing rumah warga dengan menggunakan metode pintu-ke-pintu sesuai dengan arahan Ketua RT yang menghimbau untuk tidak mengumpulkan warga dalam satu tempat dengan tetap menjalankan protokol kesehatan yang telah ada. Pembagian disinfektan disertai dengan pamflet atau brosur yang berisikan pengertian, kegunaan, cara penggunaan, bahan yang terkandung, dan cara pembuatan disinfektan. Dilakukan sosialisasi pada masyarakat agar menggunakan disinfektan dengan baik dan benar salah satunya yaitu disinfektan hanya difungsikan/disemprotkan untuk barang - barang dan tidak boleh terkena mata atau kulit, jika terkena kulit akan menyebabkan iritasi. Informasi tersebut juga tersedia dalam brosur tentang disinfektan yang dibagikan.

Keseluruhan kegiatan pembagian serta sosialisasi disinfektan berjalan lancar, namun ada faktor yang menghambat keberlangsungan acara ini, yaitu beberapa warga yang menolak untuk menerima disinfektan. Sebagian warga mengira bahwa disinfektan yang dibagikan harus membayar, sehingga mereka menolak untuk menerima. Setelah ditekankan bahwa disinfektan dibagikan secara gratis tanpa mengeluarkan biaya, warga menerima. Melalui kegiatan ini warga juga mendapat himbauan bahwa disinfektan berbeda dengan hand sanitizer. Hal ini karena sebagian masyarakat menganggap bahwa disinfektan dan hand sanitizer merupakan hal yang sama. Oleh karena itu, sosialisasi yang dilakukan juga untuk meluruskan pemahaman warga terkait disinfektan.

Pemerintah Indonesia melalui Juru Bicara Penanganan COVID-19, Achmad Yurianto dalam keterangannya di Graha BNPB, Kamis (28/5/2020) bahwa, "Sekarang satusatunya cara yang kita lakukan bukan dengan menyerah tidak melakukan apapun, melainkan kita harus jaga produktivitas kita agar dalam situasi seperti ini kita produktif 
namun aman dari COVID-19, sehingga diperlukan tatanan yang baru". Maksud dari beliau kemudian tertuang dalam pernyataan presiden RI Joko Widodo yang menyatakan pelaksanakan protokol kesehatan dengan dilaksanakannya 'Adaptasi Kebiasaan Baru'. Terkait hal ini Kementerian Kesehatan (Kemenkes) telah menerbitkan panduan lengkap penerapan Adaptasi Kebiasaan Baru. Kemenkes menerbitkan Keputusan Menkes dengan nomor HK.01.07/MENKES/328/2020 tentang Panduan Pencegahan dan Pengendalian COVID-19 di tempat kerja perkantoran dan industri dalam mendukung keberlangsungan usaha pada situasi pandemi.

Kegiatan sosialisasi gaya hidup di era adaptasi baru ini dilakukan pada hari Jum'at dan Sabtu tanggal 17 - 18 Juli 2020 pukul 09.00-14.00 WIB di titik dimana warga di Kelurahan Kalisari RT 5/RW 11 biasa berkumpul. Sosialisasi beriringan dengan kegiatan 'Jumantik' yaitu kegiatan dari ibu - ibu kader kesehatan untuk menghimbau masyarakat untuk melindungi dan menjaga kebersihan diri dan lingkungannya. Kegiatan dimulai dengan koordinasi bersama ketua RT terkait tempat sosialisasi dan pemasangan poster dan spanduk. Dalam pelaksanaanya, sosialisasi melibatkan 10 anggota kader kesehatan. Pemasangan poster dan spanduk di tempat yang sering terjadi interaksi atau dilalui masyarakat seperti pos, tempat ibadah, dan gang masuk rumah warga, sehingga masyarakat mudah mendapat informasi. Sosialisasi yang dilakukan secara pintu-ke-pintu terhadap warga dilakukan di tempat ibadah dan rumah warga yang sesuai dengan arahan kader kesehatan dan ketua RT, sosialisasi yang ditekankan kepada masyarakat adalah untuk tetap menjaga diri dan keluarga dengan berperilaku hidup bersih dan sehat.

Keseluruhan kegiatan sosialisasi serta pemasangan poster dan spanduk berjalan lancar tidak ada kendala yang berarti. Beberapa warga yang melewati poster atau spanduk menyempatkan diri untuk membaca dan melihat untuk mengetahui gaya hidup yang masih harus dipertahankan di era adaptasi kegiatan baru ini. Sosialisasi yang dilakukan kepada wargapun mendapat tanggapan positif. Hal ini dikarenakan beberapa warga mengaku bahwa tidak semua orang mengetahui bagaimana gaya hidup di era adaptasi kebiasaan baru ini. Pemasangan poster dan spanduk juga mendapat tanggapan positif dari warga seperti bantuan peralatan untuk memasang dan keingintahuan warga terhadap poster dan spanduk yang dipasang dengan membaca serta berterima kasih. Oleh karena itu, kegiatan ini dirasa bermanfaat untuk mengedukasi masyarakat.

\section{PENUTUP}

\section{Simpulan}

Hasil yang telah dicapai pada kegiataan KKN-BBM ini diantaranya adalah peningkatan pemahaman dan kesadaran masyarakat RT 5/RW 11, kelurahan Kalisari, Kecamatan Pasar Rebo, akan pentingnya menjaga kesehatan di era pandemi saat ini. Hal ini meliputi perlindungan diri dan keluarga, di rumah maupun ditempat kerja. Sehingga memaksimalkan upaya untuk memutus mata rantai penyebaran COVID-19. 


\section{Saran}

Perlu dilakukan refleksi sebagai umpan balik perencanaan tindakan pengabdian periode selanjutnya. Selain itu diperlukan tindakan atau kiat untuk menarik masyarakat agar lebih aktif lagi dalam berpartisipasi untuk menyukseskan program kerja.

\section{UCAPAN TERIMA KASIH}

Ucapan terima kasih dan penghargaan yang tinggi kepada ketua RT 5/RW 11 dan kepala kelurahan Kalisari, kecamatan Pasar Rebo, Jakarta Timur atas kerjasama dan perizinan untuk pelaksanaan KKN. Tak lupa juga ucapan terima kasih diberikan kepada Lembaga Pengabdian Masyarakat Universitas Airlangga atas dukungan selama menjalankan program melalui bimbingan, kritik dan saran koordinator wilayah dan dosen pembina pembangunan desa.

\section{DAFTAR PUSTAKA}

CDC. (2020). Dipetik Juli 22, 2020, dari https://www.cdc.gov/infectioncontrol/guidelines/disinfection/disinfectionmethods/chemical

Covid19. (2020). Dipetik Juli 23, 2020, dari https://covid19.go.id/home

Endang Lukitaningsih, I. P. (2020, April 1). Fakutas Farmasi UGM. Dipetik Juli 6, 2020, dari https://farmasi.ugm.ac.id/id/cara-penggunaan-disinfektan-yang-tepatuntuk-mencegah-penyebaran-covid-19

K. Kesehatan. (2020). Promkes Kemkes. Dipetik Juli 6, 2020, dari http://promkes.kemkes.go.id/flyer-cegah-virus-corona-dengan-germas

Rahajeng, K. (2020). cnbc Indonesia. Dipetik Juli 6, 2020, dari https://www.cnbcindonesia.com/lifestyle/20200607165856-33-163665/panduanbaru-who-masker-kain-wajib-3-lapis

WHO. (2020). who.int. Dipetik Juli 6, 2020, dari https://www.who.int/docs/defaultsource/searo/indonesia/covid19/

Worldometers.info. (2020). Dipetik Juli 23, 2020, dari https://worldometers.info/home 